\title{
Investigating Leech's Politeness Principle in Conversational Verses in Three Surahs from The Holy Quran
}

\author{
Hamid G. Jewad ${ }^{1}$, Z. Ghapanchi ${ }^{1}, \&$ M. Ghazanfari ${ }^{1}$ \\ ${ }^{1}$ Ferdowsi University of Mashhad, Mashhad, Iran \\ Correspondence: Hamid G. Jewad. E-mail: hamidjawad36@gmail.com
}

Received: December 28, 2019

Accepted: January 22, 2020

Online Published: February 27, 2020

doi:10.5539/ass.v16n3p29

URL: https://doi.org/10.5539/ass.v16n3p29

\begin{abstract}
This study has investigated three Surahs from the Holy Quran, translated into English by Arberry (1955), in terms of the Politeness Principle proposed by Leech (1983). The study aimed to investigate the kinds of politeness maxims employed by the characters in the three Surahs in question. The intentions of the speakers in observing or flouting each of Leech's politeness maxims have been categorized, including six maxims of the Politeness Principle: tact maxim, generosity maxim, approbation maxim, modesty maxim, agreement maxim, and sympathy maxim. The research had applied a mixed-methods approach in analyzing the obtained data. The data consisted of the utterances uttered by the characters in the three Surahs. After collecting the data, the data classified into six maxims of the Politeness Principle. Then, several conclusions had been drawn based on the research findings. The results of the study showed that the characters used six maxims: tact maxim, generosity maxim, approbation maxim, modesty maxim, agreement maxim, and sympathy maxim. Finally, the findings indicated that three maxims had been flouted by the characters: tact maxim, generosity maxim, and agreement maxim.
\end{abstract}

Keywords: pragmatics, Politeness Principle, politeness maxims, religious discourse

\section{Introduction}

Fraser (1983, p. 30) defines pragmatic competence as "the knowledge of how an addressee determines what a speaker is saying and recognizes the intended illocutionary force conveyed through subtle attitudes." Without this knowledge, the cases that interlocutors cannot understand each other, and failure can happen in communication. One significant feature of pragmatic competence is politeness. Politeness is defined as "the expression of the speakers' intention to mitigate face threats carried by certain face-threatening acts to another" (Mills, 2003, p. 6). The strategies by which the interlocutors can mitigate threads carried by face-threatening acts, which are called politeness strategies. Within the last two decades, different studied were made by researchers to investigate the use of the Politeness Principle in texts and social media, whereas the Politeness Principle in religious texts is very rare.

This paper aims at investigating the Politeness Principle used by the main characters in the Holy Quran. Our social relationships and politeness determine much of what we say and communicate as a means for creating, sustaining, altering, and realizing social relations. Leech $(1983$, p. 23) explains that the key role of politeness is "avoiding disruption and maintaining the social equilibrium and friendly relations." We have tried to investigate how the interlocutors (Allah, Prophets, and Humans) use the Politeness Principle in the three Surahs of the Holy Quran in their interactions with each other to bring to light how they interact with each other and how they use different politeness Maxims in the interactions.

\subsection{Theoretical background}

Politeness is one of the constructions in human interactions whose purpose is to consider other's feelings, establish levels of mutual comfort, and promote rapport (Hill, Ide, Ikuta, Kawasaki, \& Ogino, 1986). Hill et al.'s (1986) definition of politeness has seen it as 'a set of constraints', i.e., normative and perspective rules on how to interact with others, and its creditable goals are the establishment of mutual comfort and the promotion of rapport. Even stating these goals implies that there are others with other goals (Watts, 2003, p. 51). The present research aims to investigate how Leech's maxims were observed and flouted by the characters in the three Surahs (The Mary, The Cave, and The Ants) from the Holy Quran which translated by Arberry that tells about diverse 
exchange conversations between Allah, Prophets, and between human beings, six maxims are observed.

The Politeness Principle suggested to "minimize the expression of impolite beliefs" along with its less important counterpart to "maximize the expression of polite beliefs" (Leech, 1983, p. 81). Consequently, according to Leech (1983, p. 83), negative politeness has minimized the impoliteness of impolite illocutions (avoidance of discord), whereas positive politeness lies in maximizing the politeness of polite illocutions (seeking concord).

The PP divided into six maxims, and each is divided into two sub-maxims. The first represents negative politeness and the second positive politeness (Leech, 1983, pp. 32-136), as shown below:

Leech (2014, p. 35) postulates six maxims, summarized in the imperative mood as follows:

1. Tact Maxim: "Minimize cost to others, maximize the benefit to others."

a. Generosity Maxim: "Minimize benefit to self, and maximize cost to self." Minimize benefit to self;

b. Maximize cost to self

The generosity maxim used to minimize the benefit to self and maximize cost to self as well. The example is extracted from Ran (2006, p. 123):

\section{"You must come and have dinner with us." \\ "You relax and let me do the dishes."}

3. Approbation maxim: "Minimize dispraise of others; maximize praise of others."

The approbation maxim requires to minimize the dispraise of others and maximize the praise of others. This maxim is fairly apparent, operates, and proposes that all things should be made equal (in terms of responding to one another's feedback). Ran prefers to praise others, and if not, we could give some minimal responses, possibly through the use of euphemisms or remain silent (Ran, 2006, p. 123).

4. Modesty maxim: "Minimize praise to self and maximize dispraise to self."

In the modesty maxim, the speaker must minimize praise of self and maximize the dispraise of self (Leech, 1983). This maxim has the same concept as the approbation maxim. Both approbation maxim and modesty maxim focus on the degree of good or bad evaluation of others or self, which later will be expressed by the speaker through an utterance.

5. Agreement Maxim: "Minimize disagreement between self and others; maximize agreement between self and others." In the agreement maxim, a trend is to maximize agreement between self and other people and minimize disagreement between self and other (Leech, 1983). Furthermore, the disagreement usually expressed through a partial agreement or regretful expression. An example is shown in the table below. (Ran, 2006, p. 124)
A: "Linguistics is difficult to learn."
B: "True, but the phonetics is quite easy."
C: "That woman has achieved much."

6. Sympathy Maxim: "Minimize antipathy between self and others; maximize sympathy between self and others."(Almusallam, 2018). The sympathy maxim utilized to minimize antipathy between self and others and maximize sympathy between self and others. For instance, if bad luck or any disastrous events happened to an individual, one must be given sympathy or condolences (Ran, 2006, p. 124). The example illustrated below:

\section{A: "My father hurt his leg last week and still can't walk." \\ B: "I'm very sorry to hear that." (polite)}

Leech $(1983,108-109)$ finds some pragmatic scales to the maxims to determine the amount and kind of politeness. First, the cost-benefit scale measures the cost or the benefit to the speaker or addressee. The higher the cost to the hearer, the less polite the illocutionary act is, and vice versa. Second, the optionality scale, which evaluates the degree of choice in which the speaker permits the addressee on the proposed action. Third, the indirectness scale measures the amount of work incurred by the hearer in interpreting the proposed act.

According to Leech, indirect illocutions tend to be more polite than direct ones because they increase the degree of optionality and minimize the impositive force of the illocution. Fourth, the authority scale uses to measures the degree to which the speaker has the right to impose on the hearer. Finally, the social distance scale measures the degree to which the speaker and the hearer are acquainted.

Leech's politeness principle subjected to many criticisms. The chief problem in Leech's theory is its limited applicability and methodology (Jucker, 1988, pp. 376-377). The PP can only use in cooperative verbal 
interactions, i.e., polite behavior only (Bousfield, 2008, p. 51; Locher, 2004, p. 65), though his definition of politeness accommodates both polite and impolite behaviors (Eelen, 2001, p. 91). Regarding its methodology, the number of maxims is limitless and arbitrary as a new maxim can be added to account for politeness phenomena in any instance of language use (Brown \& Levinson, 1987, p. 4; Locher, 2004; Locher, 2010, 2004, p. 65; Thomas, 1995, p. 167; Turner, 1996, p. 6; Watts, 2005a, p. 46). Furthermore, the researcher cannot exactly know which maxims are to be applied at a given time (Fraser, 1990, p. 227). Some researchers have considered the PP to be too theoretical to apply to real language (e.g., Turner, 1996, p. 6; Watts, Ide, \& Ehlich, 2005, p. 7). However, Locher (2004, p. 66) states that politeness maxims apply and use to explain some motivations for politeness manifestations in British and American cultures. Therefore, Leech's model has been criticized for its culturally biased approach to Western cultures (Ide, 1989, p. 224; Matsumoto, 1988, p. 424). This may be because its examples are from English, and English emphasizes the tact maxim which mainly concerns minimizing the imposition on others.

The additional major criticism of Leech's model was that it considered linguistic behavior as inherently polite or impolite, as a consequence of his distinction between absolute and relative politeness (Bousfield, 2008, p. 53; Fraser, 1990, p. 227; Watts, 2003, p. 69). Far ahead, Leech (2007, p. 174) had discarded these terms in favor of the semantic politeness scale and pragmatic politeness scale, changing his absolute and relative politeness scales, respectively. Leech, in his $(2014$, p. 88) book "The Pragmatics of politeness," he has used the terms pragmalinguistic politeness scale (formerly absolute) and socio-pragmatic politeness scale (formerly relative). He also explains that they are two ways of looking at politeness, not two types of politeness. It appears Leech acknowledges the context's role in evaluating politeness; until now, his model still deals with pragmalinguistic politeness only, i.e., it sees politeness at the utterance level, regardless of the context. Leech's latest work does not deviate from his early framework of politeness. We understand that the change in terms had not saved Leech from the criticisms of his earlier work since he had just changed the terminology, not the definitions. Furthermore, how the socio-pragmatic politeness scale should be evaluated is still neglected and unclear in his model. Likewise, Leech had also been criticized for the PP's apparent equation of indirectness with politeness (Locher, 2004, p. 65).

Notwithstanding the critiques, we should not wholly negate the contributions that Leech's (1983) PP has done to the literature because his pioneering work has furthered our understanding of politeness. Although Leech's model focuses on absolute politeness, his inclusion of a relative way of looking at politeness can be regarded as innovative in the new paradigm of politeness models, which saw politeness at a discourse level. The present study is important because there are numerous studies in different fields, but in the Holy Quran and religious texts are very rare, so we decided to investigate these politeness maxims in the Holy Quran. Unlike most previous studies, the current research deals with politeness in religious discourse from a Socio-pragmatic point of view. It is a study of how people communicate appropriately and politely according to a set of divine rules and laws as embodied in the Holy Quran. Therefore, this study will attempt to find out the truth of polite dialogues between Prophets and their God and also between human beings and their God, even between human beings. The present exploratory study purposes of contributing towards a better understanding of how politeness in this particular type of material (i.e., the Quran) works.

\subsection{Research Purpose}

The research purposes of this study are as follows:

a. To figure out the kinds of Politeness maxims that are used in the conversational verses.

b. To explain in which Surah the Politeness maxims use more.

\section{Literature Review}

\subsection{Definition of Politeness}

Politeness is a ubiquitous term that can have different meanings in different contexts. Meier (1995) says that though there were books written on politeness, the notion was never defined. Nevertheless, he mentions the different politeness strategies that divided into positive and negative strategies. He describes how "negative strategies are characterized as expressions of restraint, formality, and distancing, whereas positive strategies are described as expressions of solidarity, intimacy, informality, and familiarity" (p. 346). Suzila and Yusri (2012) indicate that politeness is essential for communication because it considers the face needs of others. They also believe that "social distance, the formality of topic, and power difference may be affecting adherence to politeness expectations as it may mold behaviors in several ways" (p. 128).

Leech (1983) defined politeness in the book 'Principles of Pragmatics' that had published in 1983, as "forms of 
behavior that establish and maintain comity, and he proposes what he terms 'The Politeness Principle' as a way of explaining how politeness operates in conversational exchanges, indicating the ability of participants in a social interaction to engage in interaction in an atmosphere of relative harmony" (Pakzadian, 2012).

There are a few theories of politeness that have been proposed by some Linguists. According to Goffman (1967, p. 5), he states that "every person lives in a world of social encounters involving him either in face to face or mediated contact with other participants," Likewise, 'face-work' contains "the actions taken by a person to make whatever he is doing consistent with face" (Goffman, 1967, p. 12), as well as verbal behavior. "Face-saving practices", which for Goffman seem to be equivalent to "facework", are unlike for every individual, group, or society, though they may draw from a possible common framework (Goffman, 1967, p. 13). Also, Goffman discovered that interpersonal behavior is governed by moral rules imposed on a social actor from outside (Bargiela-Chiappini, 2003). These rules affect self- and other-evaluation, emotional display, and ritual practices (Goffman, 1967, p. 45). Interpersonal behavior thus defined appears to incorporate the notions of "face" (evaluation and emotional response) and "facework" (ritual practices). If "face-work" is an integral aspect of communication, should it be considered equivalent to 'politeness,' as much post-Brown and Levinson literature maintains? Then, Lakoff (1967) has proposed two overarching rules of pragmatic competence, both composed a set of sub-rules, namely be clear and be polite. In 'Logic and conversation' Grice (1989) suggested four maxims; the maxim of quantity, quality, relation, and manner, which formulated as follows (Thomas, 1995, p. 63). Based on Grice's CP maxims, Leech (1983) has suggested a theory of politeness, which is called the Politeness Principle (PP). Politeness, according to Leech, includes minimizing the benefit to the speaker/hearer.

Leech (1983) developed the Politeness Principle. There are six maxims of the Politeness Principle presented by Leech; tact maxim, approbation maxim generosity maxim, modesty maxim, agreement maxim, and sympathy maxim (Sholaikah, 2012). The center of this concept is the effect of what is said on the people. So, the speaker can speak untruth to make the hearer becoming pleasant.

According to Grice (as cited in Thomas, 1995, pp. 64-75), there are numerous occasions when people fail to observe the maxims, There are five ways of failing to find a maxim, flouting a maxim, violating a maxim, infringing a maxim, opting out of a maxim, and suspending a maxim. A flout occurs when a speaker blatantly fails to observe a maxim at the level of what is said, with the deliberate intention of generating an implicature. Then, if a speaker violates a maxim, she/he will be responsible for misleading. A speaker with no intention of generating an implicature and with no intention of deceiving fails to observe a maxim is said to 'infringe' the maxim. A speaker opts out of observing a maxim by indicating an unwillingness to cooperate in the way the maxim requires.

\subsection{Previous Studies}

\subsubsection{Geoffrey Leech's (1983) Theory}

Leech (1983), similar to Lakoff, accepted Grice's construct of conversational principle and elaborates a thorough analysis of politeness in terms of principles and maxims within a pragmatic framework in which politeness is understood as a regulative factor in interaction. In his extension of Grice's framework, Leech attempts to state why people often convey meaning indirectly. The author regards politeness as the fundamental pragmatic phenomenon for indirectness and one of the reasons why people deviate from the CP. Leech's (1983) Principles of Pragmatics provides a rhetorical model of pragmatics - defined as "the study of how utterances have meanings in situations" - and a socio-pragmatic model of rhetoric. It is a "complementarist" model where communication is seen as a problem-solving. Leech has not rejected Chomsky; rather, he seeks "a new rapprochement between grammar and rhetoric." The strongest effects on his model, he states, are Austin, Searle, and Grice. It is on Halliday's metafunctions that Leech constructs his outline of pragmatic principles. Interpersonal rhetoric subsumes the CP, the Politeness Principle (PP), and the Irony Principle (Garcia Landa, 2007). The place of the Politeness Principle (PP) in interpersonal rhetoric justified that the inability of the cooperative principle (CP) to clarify many problems that interactants may encounter.

Leech (1983) has proposed that several scales are involved in determining the type and degree of politeness: cost-benefit, optionality, indirectness, authority, and social distance. One very vital point in Leech's concept of politeness is the distinction between a speaker's illocutionary goal and a speaker's social goal. In other words, the speech act/s the speaker plans to perform by the utterance, and the situation in which the speaker adopts: being truthful, polite, and ironic, etc. He elaborates on the pragmatic framework, which consists of two main parts: textual rhetoric and interpersonal rhetoric, each of which is constituted by a set of principles. Politeness treated inside the domain of interpersonal rhetoric, which contains three sets of principles: Grice's co-operative principle (CP), which he adopts with its four maxims, his own 'Politeness Principle' (PP), and his 'irony principle' 
(IP). The author sees the IP as a second-order principle, which allows a speaker to be impolite while seeming to be polite; the speaker is ironic by superficially breaking the CP. The IP then overtly conflicts with the PP, though it enables the hearer to arrive at the point of the utterance by way of implicature, indirectly.

Leech (1983) announces a maxim-based approach following the maxims of Grice's Cooperative Principle (CP). He finds the four Maxims of Quantity, Quality, Relation, and Manner have criticized for being unclear, overlapping, or of different statuses (see, e.g., Thomas, 1995, p. 168). Leech's Politeness Principle and Maxims of Interaction had depended on a Gricean framework, he proposed the Politeness Principle (PP) and elaborated on politeness as a regulative factor in communication through a set of maxims. Politeness, as Leech (1983) found out, is a facilitating factor that influences the relationship between 'self,' the speaker, and 'other' that is the addressee/hearer and a third party.

According to Leech (1983), politeness is defined as "minimizing the expression of impolite beliefs as the beliefs are unpleasant or at a cost to it." Leech (1983) linked his Politeness Principle (PP) to Grice's Cooperative Principle (CP) in an effort to account for the violation of the $\mathrm{CP}$ in conversation.

Leech not only considers the Politeness Principle as having the same status as Grice's CP but also sees it as the reason for the non-observance of the Gricean maxims. Leech's Politeness Principle (PP) is shaped in a very similar format to the $\mathrm{CP}$ and is analyzed in terms of maxims: tact, generosity, approbation, modesty, agreement, and sympathy; all very subjective values impossible to measure. Leech has stated that in communication, the CP and the PP interact with each other; the $\mathrm{CP}$ and its maxims used to show how an utterance may be interpreted to convey indirect messages, and the PP and its maxims are utilized to explain why such indirectness might be used. Leech, similar to Lakoff, claims these two principles can conflict and that where there is a conflict, the speaker will have to sacrifice one of them. If the speaker sacrifices the PP in favor of the $\mathrm{CP}$, s/he will be putting at risk the maintenance of "the social equilibrium and the friendly relations which enable us to assume that our interlocutors are being cooperative in the first place" (1983, p. 82).

Leech explains the relationship between his Politeness Principle (PP) and Grice's Cooperative Principle (CP) as following: The $\mathrm{CP}$ allows one participant in a conversation to communicate on the assumption that the other participant is being cooperative. So, the $\mathrm{CP}$ has the task of regulating what we say so that it adds to some assumed illocutionary or discoursal good(s). It could be claimed, however, that the PP has a higher regulative role than this to preserve the social equilibrium and the friendly relationships, which enable us to suppose that our interlocutors are cooperative in the first place. Leech suggests six maxims: The Maxim of Tact, Maxim of Generosity, Maxim of Modesty, Maxim of Approbation, Maxim of Agreement, and the last Maxim of sympathy.

Leech has proposed a pragmatic framework including two components: textual rhetoric and interpersonal rhetoric, which are established by a set of principles. Politeness Principle as a subdivision is fixed within the interpersonal rhetoric domain along with two other subdivisions, that are, Grice's Cooperative Principle (CP) and Leech's Irony Principle (IP). Leech (1983) has regarded the IP as "a secondary principle which lets a speaker be impolite while seeming to be polite," in other, the speaker seems ironic by violating the cooperative. "The IP then overtly conflicts with the PP, though enables the hearer to arrive at the point of utterance by way of implicature, indirectly."

The politeness phenomenon relates to speech act. As such, Leech (1983, pp. 104-105) presents politeness via his analysis of illocutionary acts and forces. He confirms that an illocutionary act regarded as an act that foretells something. Accordingly, he categorizes illocutionary acts into four different types in the view of how "they relate to the social goal of establishing and maintaining comity." He proposed four types of illocutions (i.e., competitive, convivial, collaborative, and conflictive), two of which (i.e., competitive and convivial) involve politeness. According to Shahrokhi and Bidabadi (2013), Leech's (1983) model is related to conversational-maxim view.

The second previous research was "An Analysis of the Violations of Politeness Principles Used in English Conversation in Donald Duck Comic." The study conducted by Prihatini (2006). She used the pragmatic approach as the way of analysis. The purpose of her research is to find the types of violation and the intention of violation of politeness. The findings reveal that there are six types of Politeness Principle, and the dominant Politeness Principle is the agreement maxim; there are also eleven speaker's intentions. The most dominant intention is refusing. The other study was "An Analysis on Politeness Principles in the Expressive Act in the Movie of Pearl Harbor," conducted by Wijayanto (2009). Based on the research above, the researcher has similarities and differences. The similarities and differences are on the utterances.

The dearth of research in the holy Quran, but the researcher found some references became an inspiration to this study. Some previous studies deal with a pragmatic analysis of Leech's maxim but not in the Holy Quran but 
other fields. For example, the study was conducted by Wijayanto (2009) entitled "An Analysis on Politeness Principle in the Expressive Act in the Movie of Pearl Harbor." Her research aims to analyze the types of expressive utterances, the intention of expressive utterance, and classify the politeness principle of expressive. The results of the study reveal (1) there are ten types of expressive act used Pearl Harbor movie, (2) the intentions are ten types of expressive act, (3) there are five politeness patterns used. The second study was conducted by Oktaviani (2009) entitled "The Politeness Strategy Used by the Characters of The Lord of the Rings." The study aims at (1) how the strategy of politeness is used in a particular discourse, which is "The Lord of the Rings movie," and (2) how the situation can influence the use of strategy by using qualitative research. The results had displayed that politeness strategies were used in the movie as the work of fiction. The use of politeness strategy can be divided into four sub-strategies which are (1) bald on record, (2) positive politeness, (3) negative politeness, and (4) off-record. The results correspond to the model proposed by Brown and Levinson (1987).

Sholaikah (2011) conducted "A Study of Politeness Strategies Used by the Main Character in Persuasion Movie." This study explains how to use the politeness strategy by the main character. The purposes of the research are to determine the kinds of politeness strategies used by the main character, find the utterances that contribute to the choice of politeness strategy, describe the pragmatics scales contribute to determining the degree of politeness. The data are the utterances of the dialogue which contain maxim of politeness. Then, the result is six maxims used by the main characters in Persuasion movie.

The third is a study conducted by Ni'mah (2009) with the title "Maxim of Politeness Principle Found in "The Prince and Me" Movie." This study emphasizes the maxims of the Politeness Principle, which were found in 'The Prince and Me movie' using Leech's theory. The research aims to respond to the following questions: (1) What are the maxims of the Politeness Principle used by the characters of The Prince and Me movie, and (2) How the characters of The Prince and Me movie use the maxims of Politeness Principle. The research was conducted using a qualitative method. The outcomes of this study display that there are six maxims of the Politeness Principle used in "The Prince and Me" movie. Those six maxims are tact maxim, generosity maxim, approbation maxim, modesty maxim, agreement maxim, and sympathy maxim. The recent study uses Leech's theory in analyzing three Surahs from the Holy Quran.

According to Pakzadian (2012) declares in the book 'Principles of Pragmatics' which was published in 1983, Leech (1983) states that politeness is defined as "the forms of behavior that establishes and maintains comity," and he proposes what he terms "Politeness Principle" as an indication of the ability of participants in a social interaction; engaging in an interaction atmosphere of relative harmony." Basically, Politeness Principle is minimizing (other things being equal) the expression of impolite beliefs, and there is a corresponding positive version (maximizing [other things being equal] the expression of polite beliefs), which is somewhat less important (Leech, 1983, p. 81). Also, the study was conducted by Handayani (2013), this study aims to investigate what kinds of Politeness Principles that are violated by the advertisement and to find out what is the intention of violating such principles. The author categorized the violation through the six maxims of Politeness Principles by Leech (1983).

\subsubsection{Politeness Principle}

In 1983, Geoffrey N. Leech published his 'Principles of Pragmatics' book in London, suggesting his model of Politeness Principle, which has later been considered as the most appropriate for practical situations, the most rational and influential politeness theory (Wang, 2009). The Politeness Principle consists of maxims, in which Leech describes how politeness functions in conversational exchanges. Jiang (2010) clarifies the importance of the function of politeness towards linguistic communication and mainly concerning Politeness Principle and cooperative principle; proposed by H.P Grice as the two basic principles through which communication should be based. Leech (1983) presented the Politeness Principle, which is a crucial supplement for Grice's Cooperative Principle. This principle is considered as one of the most fundamental pragmatics principles that one frequently sees when communicating in a language.

Therefore, the Politeness Principle has proposed on how to produce and comprehend language based on politeness. In 1978, Brown and Levinson wrote an article "Universals in Language Usage: Politeness Phenomena," suggesting the degree of a broader notion and definition of politeness. Afterward, Leech has delivered his six criteria of politeness in 1983 (Huang, 2007). Both of the scholars drew great attention towards politeness theory. Leech has categorized the Politeness Principles into six maxims; each category of the principle consists of one maxim and two sub-maxims (Wang, 2009). These maxims are used to clarify the relationship between sense and force in daily interaction. These maxims are Tact Maxim, Modesty Maxim, Agreement 
Maxim, and Sympathy Maxim. Hence, these maxims will develop a more politeness conversation and thus encourages a harmonious co-existence between interactants.

\section{Research Method}

\subsection{Materials}

The data in the present study involve three Surahs; the Mary, the Cave, and the Ants from the Holy Quran. The researcher analyses these three Surahs from the original version from the Holy Quran, which was translated from the Arabic language (the original language of the Holy Quran) to the English language by Arberry (1955).

\subsection{Procedures}

The researcher of the present study used the descriptive qualitative method conducted by collecting data, classifying data, analyzing data, and drawing a conclusion. The data consists of the utterances of three Surahs in the Holy Quran, which was translated by Arberry of collecting data is documentation. The purpose of the current study extracts Leech's maxims of the Politeness Principle conducted on the pragmatic analysis found in the three Surahs from the Holy Quran. First, the researcher tries to check the accuracy of transcripts of the three Surahs. In this research, the writer used a descriptive qualitative approach, which intended to describe obtained data. We mentioned six politeness maxims proposed by Leech (1983). The researchers collected the data by reading the conversational verses of the Holy Quran and then writing them out. The researchers attempt to investigate to what extent each of the characters contributes to these six politeness maxims.

The method of collecting data was content analysis because the writer did not include in the conversation, but he read the texts. The next technique to complete the analysis method was identifying and classifying the data. The next technique to complete the analysis method was identifying and organizing the data. The writer needs to extract the data, which contain the maxims of Politeness Principles. In classifying the data, the writer used Leech's Model as the instrument of the research. By providing the frequency and percentage from their occurrence in transcripts, the researcher wants to know which character and which Surah contributes more to politeness maxims.

\subsection{Research Instruments}

As the data which collected by using the content analysis, the study uses a quantitative tool to serve qualitative purposes. Creswell (2009) points out that "Quantitative research is a means for testing objective theories by examining the relationship among variables" (p. 22). And also, we used a qualitative method in analyzing verses that contained politeness maxims. The researcher was used as data collection instrument to extract the data. The researcher read and reread the Surahs for six months to understand and extract the conversational verses, which contain the politeness maxims according to Leech's model (1983).

\subsection{The Procedure of Data Analysis}

To analyze the data, first, the researcher read and reread the verses. Then, different speech acts identified. Then, the linguistic utterances were close-read to find out in which politeness maxims they can categorize. In other words, they were coded and classified to indicate any of the politeness maxims proposed by Leech (1987). In case an utterance could be codified under more than one maxim, it was put under as many maxims as it realized.

\section{Results and Discussion}

The study divided into three parts. The first part is related to data analysis, which concerns the observant of Leech maxims, the types of maxims observed, the intention of observing the maxims. The second part was the research findings, and the last part is the discussion of the findings.

\subsection{Kinds of Leech's Maxim Used by the Characters}

One of the influential theories regarding politeness is Leech's Politeness Principle. The author had defined politeness as "different types of behaviour" which targeted at recognizing the maximum benefit for the speaker/hearer and at the same reserving the minimum cost for both of them (Leech, 1983, p. 104). In other words, the researchers can explain that politeness is "a form of behaviour which establish and maintain comity." Instead of constructing his theory on the notion of face, Leech advocated the pragmatic study of language using conversational principles to complete Grice's Cooperative Principle (CP) by a Politeness Principle (PP) in the first place. In Leech's conception, the Politeness Principle represents a set of maxims functioning on either bipolar evaluative scale of cost-benefit and praise. Or on a unipolar scale of agreement and sympathy. Politeness maxims summarized as follows: 


\subsubsection{Tact Maxim}

a) The instance from Al-Maryam Surah

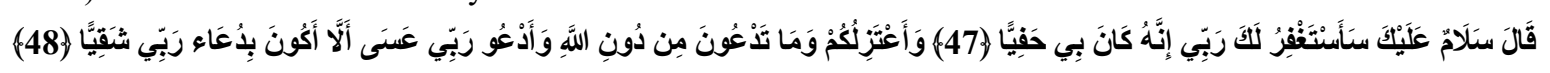

(Now I will go apart from you and that you call upon, apart from God; I will call upon my Lord, and haply I shall not be, in calling upon my Lord, unprosperous.) (Qur'an, 19: 48-49)

The Tact Maxim uses to minimize the cost to others and maximize the benefit to others. In other words, the speaker minimizes the cost (and correspondingly maximizes the profit) to the listener (Muhammad, 2010). The Tact maxim recommends the speaker to minimize the cost to the hearer and maximize the benefit to the hearer (Leech, 1983, p. 109).

\subsubsection{Generosity Maxim}

The Generosity Maxim states to minimize benefit to self and maximize cost to self. In other words, Generosity Maxim uses to minimize the expression of benefit to self and maximize the utterance of cost to self. If in the tact maxim the focus is on other-centered, in generosity maxim, it focuses on self-centered (Leech, 1983, p. 133).

\subsubsection{Approbation Maxim}

a) The instance from Al-Maryam Surah

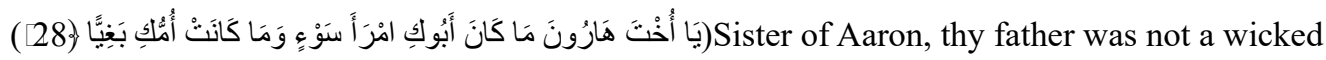
man, nor was thy mother a woman unchaste) (Qur'an,19:28.)

The Approbation Maxim is minimizing the dispraise of others and maximizing praise of others. Leech (2014), has assumed a broad interpretation of the Approbation Maxim, to include honorific titles such as lady, Duchess, and King. The Approbation Maxim advises that we should minimize the expression of beliefs that express disfigures of others; maximize the expression of beliefs that express the appraisal of others (Leech, 1983, p. 135).

\subsubsection{Modesty Maxim}

a) The instance from Al-Maryam Surah

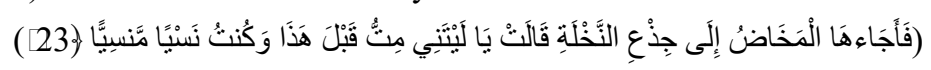

${ }_{23}$ And the birth pangs surprised her by the trunk of the palm-tree. She said, 'Would I had died before this, and become a thing forgotten!' (The Qur'an chapter 19:23. Translated by Arberry, 1955)

The Modesty Maxim is minimizing praise of self and maximizing the dispraise of self. It is applied in representative/assertive and expressive speech acts. This maxim informs that "we should minimize praise of self as well as maximize disfigure of self" (Leech, 1983, p. 136).

\subsubsection{Agreement Maxim}

a) Instance from Al-Kahf Surah

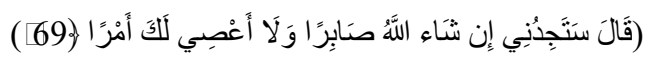

(He said, 'Yet thou shalt find me, if God will, patient; and I shall not rebel against thee in anything) (Qur'an, 18:69)

There is a tendency to maximize agreement between self and other people and minimize disagreement between self and other.

\subsubsection{Sympathy Maxim}

a) The instance from the Ants Surah

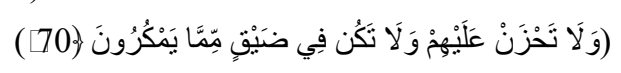

(Do not sorrow for them, nor be thou straitened for what they devise) (Qur'an, 27:70.)

Sympathy maxim uses to minimize antipathy and maximize sympathy between self and other. In the sympathy maxim, the applicant expected to maximize the expression of sympathy to their hearers and minimize the antipathy. This maxim usually used in representative utterances (Leech, 1983, p. 138).

Leech (1983) states that it is not that all of the maxims and sub-maxims are equally important. Instead, of the twinned maxims (1)-(4), (1) appears to be a more powerful constraint on conversational behavior than (2) and (3) than (4). This reflects a more general law that politeness focused more strongly on other than on self. Furthermore, it is evident that within each maxim, sub-maxim (b) seems to be less important than sub-maxim (a), 
which illustrates the more general law that negative politeness or avoidance of discord is a weightier consideration than positive politeness or seeking concord.

Table 1. Frequency and percentage of the Tact Maxim as \% of characters/Surahs

\begin{tabular}{cccc}
\hline Characters/Surahs & Mary & Cave & Ants \\
\hline Allah & $1(5.2 \%)$ & - & - \\
Prophet & & - & - \\
Humans & $1(5.2 \%)$ & - & - \\
\hline
\end{tabular}

Table 1 shows to what extent each character contributes to the Tact maxim. This maxim relates to the reality that when we minimize benefit to ourselves and maximize the benefit to others, we are more concerned with Politeness Principle, and connectedness to group and others is a more important issue for us. The results of Table 1 show that Prophet and humans used the Tact Maxim in the Mary Surah, whereas there is no one used this maxim in the Cave and Ants Surahs. Table 1 shows that the characters, Allah and the Prophet, used this maxim as in the following conversational verses.

\section{Extract 1}

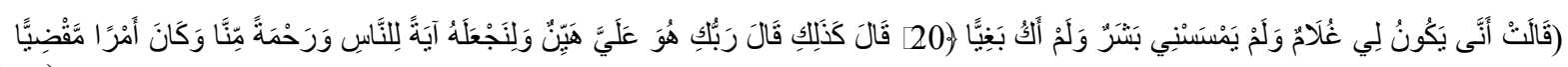

(She said, 'How shall I have a son whom no mortal has touched, neither have I been unchaste?) ${ }_{21}$ He said, 'Even so thy Lord has said: "Easy is that for Me; and that We may appoint him a sign unto men and a mercy from Us; it is a thing decreed." (Qur'an, 19: 20-21) in this verse, Allah used the tact maxim when he said: "Easy is that for Me; and that We may appoint him a sign unto men and a mercy" to minimize the cost to Mary and maximize the benefit to her.

Extract 2

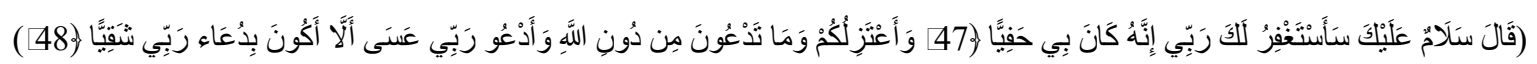

48 "Now I will go apart from you and that you call upon, apart from God; I will call upon my Lord, and haply I shall not be, in calling upon my Lord, unprosperous."

It implies that the act of "I will call upon my Lord, and haply I shall not be, in calling upon my Lord, unprosperous" is for the benefit to his father. He tells him he will call upon his lord. So, the character is observing tact maxim in Politeness Principle. It can be known by seeing the utterance that the benefit is to his father, and the cost is to him.

Table 2. Frequency and percentage of the Generosity Maxim as \% of characters/Surah

\begin{tabular}{cccc}
\hline Characters/Surahs & Mary & Cave & Ants \\
\hline Allah & - & - & - \\
Prophet & - & - & - \\
Humans & - & - & - \\
\hline
\end{tabular}

Table 2 shows that no one used the generosity maxim in all Surahs.

Table 3. Frequency and percentage of the Approbation Maxim as \% of characters/Surahs

\begin{tabular}{cccc}
\hline Characters/Surahs & Mary & Cave & Ants \\
\hline Allah & - & - & - \\
Prophet & - & - & - \\
Humans & $1(5.2 \%)$ & - & - \\
\hline
\end{tabular}

Table 3 shows that human beings used approbation maxim in Mary Surah, where the other Surahs no one used this maxim. 
The Approbation Maxim uses to minimize the dispraise of others and maximize the praise of others. It consists of two parts: (a) Minimize the dispraise of others [(b) Maximize praise of others] (Pakzadian, 2012, p. 327).

\section{Extract 3}

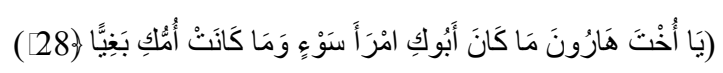

${ }_{28}$ Sister of Aaron, thy father was not a wicked man, nor was thy mother a woman unchaste. (Qur'an, 19:28)

This utterance expresses that the people praised and raised her family. So, they try to use the politeness approbation maxim. They said that her father was not a wicked man, and her mother was not unchaste. The utterance above has maximized the praise of others or minimized the dispraise of others.

Table 4. Frequency and percentage of the Modesty Maxim as \% of characters/Surahs

\begin{tabular}{cccc}
\hline Characters/Surahs & Mary & Cave & Ants \\
\hline Allah & - & - & - \\
Prophet & - & - & - \\
Humans & $2(10.5 \%)$ & - & $1(5.2 \%)$ \\
\hline
\end{tabular}

Modesty Maxim uses to minimize praise of self and maximize the dispraise of self. It consists of two parts, (a) Minimize praise of self [(b) Maximize dispraise of self]. Table 4 shows that humans used this maxim two times in Mary Surah and one time in the Ants Surah

\section{Extract 4}

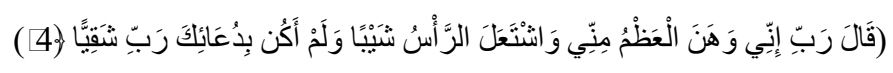

4 saying, 'O my Lord, behold the bones within me are feeble, and my head is all aflame with hoariness. And in calling on Thee, my Lord, I have never been hitherto unprosperous. (Qur'an, 19:4)

The utterance above is minimizing praise or maximizing the dispraise of self. When the Prophet said: "O my Lord, behold the bones within me are feeble, and my head is all aflame with". The Prophet uses this maxim to express his polite speech with Allah. And also, when he said, "O my lord," he explains that was humble, and also, he raises the position of Allah. In this case, the Prophet dispraises himself and disfigures Allah.

Extract 5

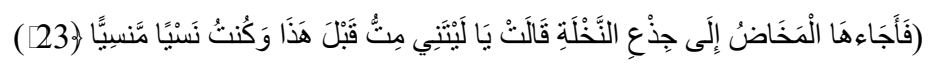

${ }_{23}$ And the birth pangs surprised her by the trunk of the palm-tree. She said, 'Would I had died before this, and become a thing forgotten!' (Qur'an, 19:23)

Mary here dispraised herself when she said, 'would I had died, and become a thing forgotten.' Mary uses this utterance to be more polite.

Table 5. Frequency and percentage of the Agreement Maxim as \% of character/Surahs

\begin{tabular}{cccc}
\hline Characters/Surahs & Mary & Cave & Ants \\
\hline Allah & - & - & - \\
Prophet & - & $4(21.05 \%)$ & - \\
Humans & $2(10.5 \%)$ & - & $3(15.7 \%)$ \\
\hline
\end{tabular}

\section{Agreement maxim}

Agreement Maxim proposes that you should minimize the expression of disagreement between self and others (Leech, 1983, p. 138). Thus, this maxim told us to agree with other's words.

Table 5 shows that humans used this maxim two times in Mary Surah, Prophets used this maxim four times in Cave Surah, and humans used this maxim three times in the Ants Surah.

There is a purpose to maximize agreement between self and other people and minimize disagreement between self and other.

Extract 7

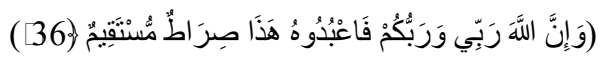


${ }_{36}$ 'Surely God is my Lord, and your Lord; So serve you Him'. This is a straight path. (Qur'an, 19:36)

This conversational verse reveals that the Prophet used the agreement maxim to avoid disagreement when he said: "Indeed, Allah is my Lord and your Lord, therefore, worship Him. That is the Straight Path". He used this maxim to be more polite with his nation to ask them to worship Allah without ordering them to do that.

Extract 8

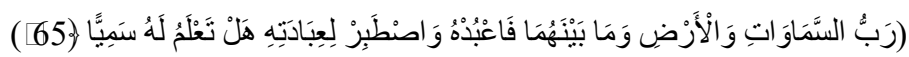

65 And thy Lord is never forgetful, Lord He of the heavens and earth and all that is between them. So, serve Him, and be thou patient in His service; knowest thou any that can be named with His Name? (Qur'an, 19:65)

Also, the Prophet here avoids disagreement with his nation when he used this maxim to be more polite. The utterance above used to maximize agreement or minimize disagreement between self and others.

Extract 9

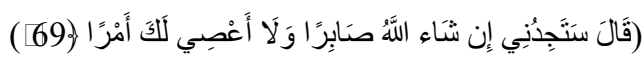

69 He said, 'Yet thou shalt find me if God will, patient; and I shall not rebel against thee in anything. ' (Qur'an, 18:69)

The Prophet said: you shall find me, if God will, patient, and I shall not rebel against you in anything. Here tries to minimize disagreement and maximize agreement with the Prophet (Ilyas).

Extract 10

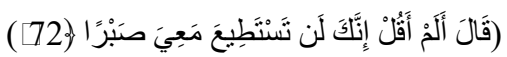

72 Said he, 'Did I not say that thou couldst never bear with me patiently? ' (Qur'an, 18:72)

The conversational verse above explains that the Prophet (Ilyas) used this maxim to avoid disagreement with the Prophet (Moses).

Extract 11

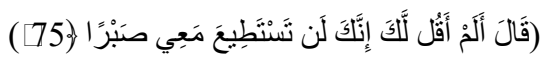

75 Said he, 'Did I not say that thou couldst never bear with me patiently? ' (Qur'an, 18:75)

Here also repeated the verse to try to avoid disagreement with the Prophet (Moses).

Extract 12

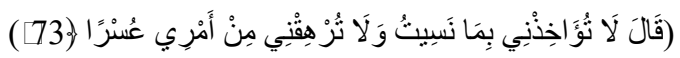

73 He said, 'Do not take me to a task that I forgot, neither constrain me to do a thing too difficult. (Qur'an, 18:73)

Extract 13

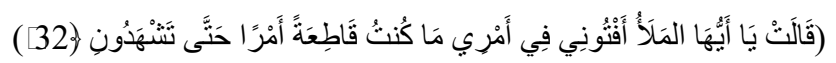

${ }_{32}$ She said, 'O Council, pronounce to me concerning my affair; I am not used to deciding an affair until you bear me witness. (Qur'an, 27:32)

In this verse, the woman (the Queen) said: "O Council, let me hear your counsel, concerning my affairs, for I am not used to deciding an issue until you bear me witness." She used the Maxim of Agreement to avoid the disagreement between her and her council, so she asks them to pronounce to her.

\section{Extract 14}

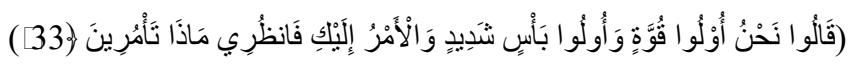

33 They said, 'We possess force, and we possess great might. The affair rests with thee; so consider what thou wilt command. ' (Qur'an, 27:33)

They used the Maxim of the agreement to express their polite opinion of what she commands them.

Here her council replied: 'We are possessors of power and great might. It is for you to command, so consider what you will.' they gave their opinion to avoid disagreeing with their Queen.

\section{Extract 15}

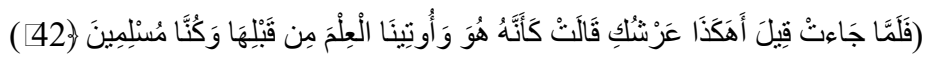

42 "So, when she came, it was said, 'Is thy throne like this? ' She said, 'It seems the same.” (Qur'an, 27:42.) 
The Queen used politeness maxim (Maxim of agreement) to express her partial agreement or to avoid disagreement with the Prophet Solomon.

Table 6. Frequency and percentage of the Sympathy Maxim as \% of characters/Surahs

\begin{tabular}{cccc}
\hline Characters/Surahs & Mary & Cave & Ants \\
\hline Allah & $2(10.5 \%)$ & - & $2(10.5 \%)$ \\
Prophet & - & - & - \\
Humans & - & - & - \\
\hline
\end{tabular}

Table 6 shows That Allah used this maxim two times in Mary Surah and the Ants Surah, whereas Prophets and Humans did not use it in any Surah.

Sympathy maxim describes to minimize antipathy and maximize sympathy between self and other.

Extract 16

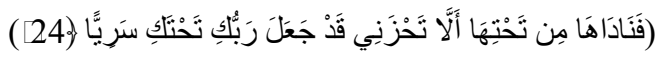

${ }_{24}$ But the one that was below her called to her, 'Nay, do not sorrow; see, thy Lord has set below thee a rivulet. The datum, which found in verse 24, is the conversation between Allah and Mary. Here in this verse, Allah used with his servant Marry the sympathy maxim to maximize and relieve her sorrow. (Qur'an, 19:24)

Extract 17

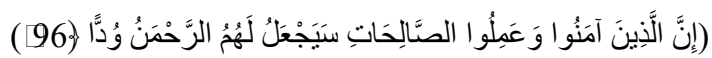

${ }_{96}$ Surely, those who believed and did deeds of righteousness -- unto them the All-merciful shall assign love. Also, Allah uses the sympathy maxim when he said: "unto them, the All-merciful shall assign love." (Qur'an, 19:96)

It means Allah will love them.

Extract 18

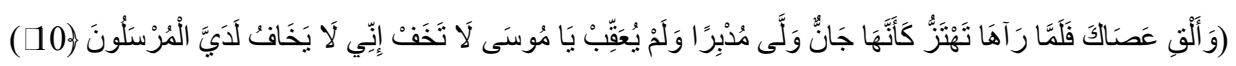

10 "Cast down thy staff. And when he saw it quivering like a serpent, he turned about, retreating, and turned not back. 'Moses, fear not; surely the Envoys do not fear in My presence." (Qur'an, 27:10)

Extract 19

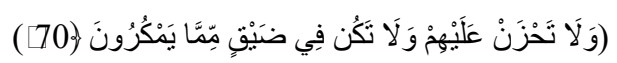

${ }_{70}$ Do not sorrow for them, nor be thou straitened for what they devise. (Qur'an, 27:70)

Table 7. Frequency and Percentage of the Politeness Principle in the tree Surahs

\begin{tabular}{llll}
\hline Politeness Principle/ Surahs & Mary & Cave & Ants \\
\hline Tact Maxim & $4(21.05 \%)$ & - & - \\
Generosity maxim & - & - & - \\
Approbation Maxim & $1(5.2 \%)$ & - & - \\
Modesty Maxim & $2(10.5 \%)$ & - & $1(5.2 \%)$ \\
Agreement Maxim & $2(10.5 \%)$ & $4(21.05 \%)$ & $3(15.7)$ \\
Sympathy Maxim & $2(10.5 \%)$ & - & $2(10.5 \%)$ \\
\hline
\end{tabular}

\section{Conclusion}

Table 7 reveals the distribution of the Politeness Principle in the Surahs (Mary, Cave, and the Ants). The distribution of Tact Maxim was the highest in the Mary Surah 4(21.05\%) and the distribution of the Agreement Maxim in the Cave Surah was also the highest 4(21.05) amongst the others Surahs. And also, this study explains that there is no one of the characters (Allah, Prophets, and Humans) used the Generosity Maxim in the three Surahs. The 'agreement maxim' in Mary Surah was the most frequent in this data. The paper attempts to explore 
politeness maxims through language in the conversational verses that happened among the main characters in the Holy Quran (Allah, Prophets, and Humans) in three Surahs (Mary, Cave, and the Ants). The researcher can conclude that there are six maxims observed and flouted politeness maxims by the characters (Allah, Prophet, Humans). The characters used six maxims of the Politeness Principle, according to Leech's (1983) model. They are tact maxim, generosity maxim, approbation maxim, modesty maxim, agreement maxim, and sympathy maxim. The 'agreement maxim' in the Mary Surah is the most dominant maxim that is used by the characters in the three Surahs from the Holy Quran translated by Arberry.

The findings of the current study can be an excellent contribution to understand politeness in religious texts, especially religious texts such as the Holy Quran. According to leech's (1983) conception of politeness, using politeness maxims are promising factors in softening the bitter effect of the given acts, henceforth fostering interpersonal relationships amongst the members in a particular society.

The agreement maxim has a remarkably higher frequency in the data, then following agreement maxim in the Cave Surah. In Mary Surah, which is minimizing disagreement and maximizing agreement between yourself and others. It aimed to teach how to speak in polite communication, make a good social relationship, and more closely. There are some suggestions for the readers and other researchers who are doing similar research in the next time, which gives the reference for the people who have difficulties in comprehending Leech's maxim of Politeness Principle. The Holy Quran also can be a good reference to look for examples of Leech's maxim to learn the Politeness Principle and to apply Leech's (1983) model. The research is divided into six sub-sections in accordance with Leech's maxims of politeness, (1) The Tact Maxim, (2) The Generosity Maxim, (3) Approbation Maxim, (4) Modesty Maxim, (5) Agreement Maxim, and (6) Sympathy Maxim.

\section{References}

Almusallam, I. I. A. (2018). A Discursive Approach to Politeness: Negotiating Offers in Women's Talk by Saudi Arabic and British English Speakers. University of Leeds,

Arberry, A. J. (1955). The Koran Interpreted: Suras XXI-CXIV (Vol. 2): Allen \& Unwin.

Bargiela-Chiappini, F. (2003). Face and politeness: new (insights) for old (concepts). Journal of Pragmatics, 35(10-11), 1453-1469.

Bousfield, D. (2008). Impoliteness in interaction. Amsterdam: John Benjamins Publishing Company.

Brown, P., \& Levinson, S. C. (1987). Politeness: Some universals in language usage (Vol. 4). Cambridge University Press.

Creswell, J. W., \& Zhang, W. (2009). The application of mixed methods designs to trauma research. Journal of Traumatic Stress: Official Publication of The International Society for Traumatic Stress Studies, 22(6), 612-621.

Eelen, G. (2001). A Critique of Politeness Theories. Manchester: St. Jerome Publishing.

Fraser, B. (1983). The domain of pragmatics. In J. Richards, \& R. Schmidt, (Eds.), Language and communication. London: Longman.

Fraser, B. (1990). Perspectives on politeness. Journal of Pragmatics, 14(2), 219-236.

Garcia Landa, J. A. (2007). Netiquette, Politeness, Strategy and Wisdom. Available at SSRN 1030361.

Goffman, E. (1967). On face-work. Interaction ritual, 5-45.

Handayani, T. (2013). Violating politeness principles in cellular phone provider. LANTERN (Journal on English Language, Culture and Literature), 2(3), 293-303.

Hill, B., Ide, S., Ikuta, S., Kawasaki, A., \& Ogino, T. (1986). Universals of linguistic politeness: Quantitative evidence from Japanese and American English. Journal of Pragmatics, 10(3), 347-371.

Huang, Y. (2007). Pragmatics. Oxford: Oxford University Press.

Ide, S. (1989). Formal forms and discernment: Two neglected aspects of universals of linguistic politeness. Multilingua-Journal of Cross-Cultural and Interlanguage Communication, 8(2-3), 223-248.

Jiang, X. (2010). A Case Study of Teacher's Politeness in EFL Class. Journal of Language Teaching \& Research, $1(5)$.

Jucker, A. H., \& IDE, S. (1988). The Relevance of Politeness in Linguistic Politeness I. Multilingua, 7(4), 375-384. 
Lakoff, G. (1967). On the nature of syntactic irregularity. Washington: ERIC/PEGS Clearinghouse for Linguistics, Center for Applied Linguistics.

Leech, G. (1983). Principles of Pragmatics. London: Longman.

Leech, G. (2007). Politeness: is there an East-West divide? Journal of Politeness Research. Language, Behaviour, Culture, 3(2), 167-206.

Leech, G. N. (1987). Meaning and the English Verb: (by) Geoffrey N. Leech: Longmans.

Leech, G. N. (2014). The pragmatics of politeness. Oxford University Press, USA.

Locher, M. A. (2004). Power and Politeness in Action: Disagreements in Oral Communication. Berlin/New York: Mouton de Gruyter.

Locher, M. A. (2010). Power and politeness in action: Disagreements in oral communication (Vol. 12). Walter de Gruyter.

Matsumoto, Y. (1989). Politeness and conversational universals-observations from Japanese. Multilingua-Journal of Cross-Cultural and Interlanguage Communication, 8(2-3), 207-222.

Meier, A. J. (1995). Passages of politeness. Journal of pragmatics, 24(4), 381-392.

Mills, P. (2003). Approaches to Pragmatics. New York: MIT Press.

Muhammad, H. B. (2010). Politeness Theory in Dialogs in the translation of Naguib Mahfouz's Trilogy Mena University.

Ni'mah, D. (2009). Maxims of Politeness Principles Found in "The Prince and Me" Movie. Graduating Research.

Oktaviani, F. H. (2009). The Politeness Strategies Used by the Characters of The Lord of the Rings. SKRIPSI Jurusan Sastra Inggris-Fakultas Sastra UM.

Pakzadian, M. (2012). Politeness principle in 2008 presidential debates between Mc Cain and Obama. Mediterranean Center of Social and Educational Research, 3, 351.

Prihatini, Y. (2006). An Analysis of the Violations of Politeness Principle Used in English Conversation In Donald Duck Comic. Muhammadiyah University of Surakarta,

Saffarzadeh, T. (2012). The Holy Qur'an. Qum: Osveh.

Shahrokhi, M., \& Bidabadi, F. S. (2013). An overview of politeness theories: Current status, future orientations. American Journal of Linguistics, 2(2), 17-27.

Sholaikah, F. N. (2012). A study of politeness strategies used by the main character in persuasion movie. Universitas Muhammadiyah Surakarta.

Suzila, T. T. I., \& Yusri, M. M. (2012). Politeness: Adolescents in disagreements. International Journal of Social Science and Humanity, 2(2), 127.

Thomas, J. (1995). Meaning in Interaction: An Introduction to Pragmatics. Harlow: Pearson Education.

Turner, K. (1996). The principal principles of pragmatic inference: politeness. Language Teaching, 29(1), 1-13.

Wang, Z. (2009). Raising and Lowering Speaker's or Hearer's Position in the Politeness Principle in Interculural Communication. Intercultural Communication Studies, 18(1), 286.

Watts, R. J. (2003). Politeness. New York: Cambridge University Press.

Wijiyanto, W. (2009). An Analysis on Politeness Principles in the Expressive Act in the Movie of "Pearl Harbor." Universitas Muhammadiyah Surakarta.

\section{Copyrights}

Copyright for this article is retained by the author(s), with first publication rights granted to the journal.

This is an open-access article distributed under the terms and conditions of the Creative Commons Attribution license (http://creativecommons.org/licenses/by/4.0/). 